\title{
Peran dan Kewajiban Perawat Sebagai Pemberi Asuhan Keperawatan di Rumah Sakit
}

Nama : Khairun Nisa

Email : k.khairunnisa1311@gmail.com

\begin{abstract}
:
Nurses who are medical personnel who serve the community have an obligation to provide nursing care. The services provided must meet the standards and in accordance with the expertise and skills they have. There are many roles for nurses in the hospital, including. providing nursing care, educator, advocate, client, counselor, change agent, leader, manager, special manager, and researcher and developer of nursing practice. equal or even more than what they expected. nurses have 2 roles, the first treatment is assistance that is provided when the patient is experiencing physical weakness, mental weakness, limited knowledge, and the inability to carry out daily activities. Second, namely: the condition in which the patient is experiencing illness, in an effort to heal and recover, and to maintain health by expecting services in accordance with the authority and abilities, as well as the ethics and responsibilities of the nurse. . In carrying out their roles, nurses must not look at patients from social, cultural, ethnic, racial and religious terms. Nurses are expected to be able to provide nursing care to patients with full trust based on the patient's culture and beliefs.
\end{abstract}

Key Word : roles, obligations, nursing care

\begin{abstract}
ABSTRAK:
Perawat yang merupakan salah satu tenaga medis yang bertugas melayani masyarakat memiliki kewajiban dalam memberi asuhan keperawatan. Layanan yang diberikan harus memenuhi standar dan sesuai dengan keahlian dan keterampilan yang dimilikinya. Ada banyak peran perawat di rumah sakit antara lain: memberikan asuhan keperawatan, pendidik, advokat, klien, konselor, agen pengubah, pemimpin, manajer, manajer khusus, serta peneliti dan pengembang praktik keperawatan. Perawat memiliki 2 peran, yang pertama perawatan adalah bantuan yang biberikan ketika pasien sedang mengalami kelemahan fisik, kelemahan mental, keterbatasan pengetahuan, serta ketidak mampuan dalam melaksanakan kegiatan sehari-hari. Yang kedua yaitu: kondisi dimana pasien sedang mangalami sakit, dalam upaya penyembuhan dan pemulihan, serta memelihara kesehatan dengan yang mengharapkan pelayanan yang sesuai dengan kewenangan dan kemampuan, serta etika dan tanggung jawab perawat. . Dalam menjalankan perannya perawat tidak boleh memanadang pasien dari sosial, budaya, suku, ras dan agama. Perawat diharapkan mampu memberikan asuhan keperawatan kepada paien dengan kepercayaan penuh berdasarkan budaya dan keyakinan pasien.
\end{abstract}

Kata Kunci : peran, kewajiban, asuhan keperawatan. 


\section{LATAR BELAKAN}

Perawat merupakan salah satu tenaga medis tugasnya melayani masyarakat dan memiliki kewajiban dalam memberi asuhan keperawatan. Setiap kewajiban dan peran yang dijalankan haruslah sesuai dengan kewenangan orang itu sendiri, begitu juga dengan perawat, perawat harus menjalankan peran dan kewajibannya sebagai seorang perawat berdasarkan wewenang yang ia miliki. Ada banyak peran perawat di rumah sakit antara lain: memberikan asuhan keperawatan, pendidik, advokat, klien, konselor, agen pengubah, pemimpin, manajer, manajer khusus, serta peneliti dan pengembang praktik keperawatan. tindakan dan keputusan yang di ambil perawat harus dilaksanakan secara komprehensif, bukan hanya berfokus pada tindakan promotif tetapi juga pada tindakan preventif kepeda individu yang sedang membutuhkan pelayanan.

Sakit merupakan kondisi abnormal yang dapat mengganggu kenyamanan seseorang. ada banyak faktor yang membuat seseorang itu mengalami sakit bisa karena asupan nutrisi yang tidak mencukupi, kecelakaan, lingkungan, strees dan lain-lain. kondisi abnormal ini jika di biarkan bisa merugikan banyak pihak, bukan hanya individu, namun juga lingkungan sekitar seperti keluarga, tetangga, bahkan jika pasien ini mengalami penyaki infeksi ia bisa membuat banyak orang terinfeksi. Oleh karena itu Sebelum sakit tersebut menjadi masalah yang lebih serius maka lebih baik kita mengambil keputusan sedini mungkin.

Ada banyak alternatif yang bisa di ambil ketika kita sedang terserang penyakit, salah satunya adalah rumah sakit. Rumah sakit merupakan instansi pelayanan yang digunakan untuk melayani masyarakat yang sedang sakit atau yang sedang membutuhkan konsultasi. Rumah sakit menyediakan perawatan mulai dari rawat inap, rawat jalan, dan gawat darurat. di rumah sakit tersebut ada banyak profesi yang saling berkolaborasi guna memberi layanan yang baik sehingga kepuasan pasien dapat tercapai. Kepuasan pasien merupakan perasaan lega dan merasa senang terhadap pelayanan dan asuhan yang di dapatkan selama di rumah sakit. Penelitian di Amerika Serikat terkait kepuasan klien/pasien terhadao pelayanan yang diberikan perawat yaitu 10 orang pasien yang berkunjung ke IGD ditemukan 6 pasien mengeluh terhadap pelayanan yang diberikan perawat, sedangkan 4 lainnya menyebutkan ketidak puasannya terkait fasilitas yang diberikan relatif lama dan memiliki proses yang rumit. 
Perawat yang merupakan salah satu tenaga medis yang bertugas melayani masyarakat memiliki kewajiban dalam memberi asuhan keperawatan. Layanan yang diberikan harus memenuhi standar dan sesuai dengan keahlian dan keterampilan yang dimilikinya. Kepuasan pasien merupakan bukti bahwa perawat telah mampu memenuhi harapan-harapan yang meliputi pelayanan yang baik, ketepatan waktu dalam melayani, dan memberikan informasi yang sebenar-benarnya. Pasien baru akan merasa puas apabila pelayanan yang ia dapatka sama atau bahkan melebihi dari apa yang mereka harapkan. Perawat dalam memberikan asuhan bukan hanya berperan dalam melayani individu yang sedang sakit, namun bisa juga berhadapan dengan klien yang membutuhkan pendidikan kesehatan maupun konsling tentang masalah yang ia sedang hadapi. Secara fisiologi perawat memiliki 2 peran, yang pertama perawatan adalah bantuan yang biberikan ketiaka pasien sedang mengalami kelemahan fisik, kelemahan mental, keterbatasan pengetahuan, serta ketidak mampuan dalam melaksanakan kegiatan sehari-hari. Yang kedua yaitu: kondisi dimana pasien sedang mangalami sakit, dalam upaya penyembuhan dan pemulihan, serta memelihara kesehatan dengan yang mengharapkan pelayanan yang sesuai dengan kewenangan dan kemampuan, serta etika dan tanggung jawab perawat. Setiap tindakan yang di ambil perawat harus sesuai dengan diagnosis masalah yang terjadi. Sebelum menentukan diagnosis harus menganalisis masalah pasien mulai dari fisik sampai pada masalah psikolog.

\section{METODE PENELITI}

Penelitian ini merupakan jenis penelitian kualitatif, yang mana sumber referensinya di ambil dari jurnal terpercaya guna mendapatkan informasi yang akurat . tujuan penelitian ini adalah untuk mendapatkan informasi tentang asuhan keperawan dan peran yang dijalankan oleh perawat dalam melakukan tindakan keperawatan di rumah sakit. dengan adanya penelitian ini diharapkan dapat membantu pembaca mendapatkan informasi terkain tema ini. 


\section{HASIL}

Hasil penelitian yang didapatkan Sesuai dengan Ketentuan dalam pasal 37 Undang-Undang Nomor 38 Tahun 2014 Tentang kewajiban keperawatan yang mewajibkan perawat agar melegkapi prasarana pelayanan berdasarkan standar pelayanan keperawatan, memberikan pelayanan yang maksimal, melakukan perujukan kepada perawat lain apabila tidak mampu menyelesaikan suatu hal, melakukan pendokumentasian, menyampaikan informasi yang sebenar-benarnya, jujur, jelas, serta mudah dipahami terkait tindakan yang dilakukan perawat agar pasien tahu tentang oerkembangan kesehatannya. Dengan perawat telah melakukan kewajibannya, agar jika terjadi sesuatu kesalahan, maka perawat dapat bertanggung jawab. Dalam memberikan asuhan keperawat, perawat harus melakukan tindakan sebik-baik mungkin, perawat harus mampu memenuhi kebutuhan pasien, melindungi hak-hak pasien, menjaga privasi pasien, dan membantu pasien dalam menghadapi masalah yang ia jalani. Berbicara tentang layanan dan asuhan, perawat harus berkerja semaksimal mungkin, agar mendapatkan hasil yang memuaskan. Dengan begitu pasien akan merasa puas tanpa ada rasa kecewa.

\section{PEMBAHASAN}

Istilah peran bisa di artikan sebagai seperangkat perilaku yang menjadi harapan individu yang berdasarkan dengan status sosialnya. Sedangkan kewajiban adalah segala sesuatu yang harus diperbuat atau wajib dilakukan, kewajiban terbagi atas 2 macam yaitu kewajiban sempurna yang berarti bahwa kewajiban ini selalu berkaitan dengan hak orang pain, dan kewajiban tidak sempurna yaitu terkait dengan dengan hak orang lain. kewajiban sempurna merupakan jenis keadilan yang berlandaskan keadilan, sedangkan keadilan tidak sempurna yaitu keadilan yang berdasarkan moral. 
Kewajiban Dan Hak Perawat Berdasarkan Undang-Undang Nomor 36 Tahun 2009

Tentang Kesehatan. Kewajiban perawat berdasarkan Pasal 9, Pasal 10, Pasal 11, Pasal 12 dan Pasal 13 dinyatakan bahwa:

1. Setiap orang berkewajiban, mewujudkan, mempertahankan, dan meningkatkan derajat kesehatan masyarakat yang setinggi-tingginya.

2. Kewajiban sebagaimana dimaksud pada Ayat tersebut

3. Pelaksanaannya meliputi upaya kesehatan perseorangan, upaya kesehatan masyarakat, dan pembangunan berwawasan kesehatan; Setiap orang berkewajiban menghormati hak orang lain dalam upaya memperoleh lingkungan yang sehat, baik fisk, biologi, maupun sosial; Setiap orang berkewajiban berperilaku hidup sehat untuk mewujudkan, mempertahankan dan memajukan kesehatan yang setinggi-tingginya; Setiap orang berkewajiban menjaga dan meningkatkan derajat kesehatan bagi orang lain yang menjadi tanggung jawabnya;

(1) Setiap orang berkewajiban turut serta dalam program jaminan kesehatan sosial

(2) Program jaminan kesehatan sosial sebagaimana dimaksud pada Ayat (1) dikhususkan pada pelayanan publik.

Sedangkan ketentuan dalam Pasal 56 Undang-Undang Nomor 6 Tahun 2009 Tentang kesehatan dinyatakan bahwa :

1) Perawat berhak untuk mendapatkan perlindungan hukum dalam melaksanakan tugas sesuai dengan profesinya;

2) Perawat berhak mengembangkan diri melalui kemajuan sosialisasi sesuai dengan latar belakang pendidikannya;

3) Perawat berhak menolak keinginan pasien yang bertentangan dengan peraturan perundang-undangan serta standar dan kode etik profesi perawat;

4) Perawat berhak mendapatkan ilmu pengetahuan berdasarkan perkembangan ilmu pengetahuan dan teknologi dalam bidang keperawatan atau kesehatan secara terus menerus;

5) Perawat berhak untuk mendapatkan penghargaan dan imbalan yang layak atas jasa profesi yang diberikannya berdasarkan perjanjian atau ketentuan yang berlaku di Institusi pelayanan yang bersangkutan.

Menjadi seorang perawat yang profesional bukanlah hal yang mudah. Ada banyak halhal yag harus kita hadapi contohnya seperti menumbuhkan citra di masyarakat terkait profesi perawat merupakan hal yang butuh pembuktian dan keprofesionalan perawat tersebut baik 
dalam melayani, dalam bersikap, maupun dalam mengambil keputusan yang benar. Menjadi profesional itu memiliki tantangan yang besar, Namun apa boleh buat karena hal tersebut sudah menjadi keharusan agar kita sebagai perawat mampu berperan sedengan semestinya tanpa ada kekhawatiran dan rasa takut. keprofesionalan dapat mengubah citra perawat ideal yang lebih baik di mata masyarakat dengan mengasah kompetensi, memiliki kemauan yang besar, keseriusan si perawat dalam merubah citra. Perawat yang terampil, cerdas, baik, komunikatif dan dapat menjalankan peranrapkan fungsinya dengan baik sesuai dengan kode etik merupakan tarap keidealan yang dihapkan. Setiap pasien memiliki harapan yang lebih terhadap perawat, mereka mengharapkan layanan yang baik, dan mampu menyelesaikan keluhan yang mereka rasakan.

Di Rumah sakit perawat dituntut untuk memberikan asuhan keperawatan sesuai dengan standar profesinya, yang terdiri dari: pengkajian, menetapkan diagnosa, perencanaan, pelaksanakan tindakan keperawatan, dan evaluasi. Tindakan keperawatan meliputi: intervensi, observasi, pendidikan dan konseling, sesuai dengan standar asuhan keperawata yang ditentukan oleh organisasi profesi. Peran perawat dalam memeberi asuhan merupakan kewajiban yang paling penting dalam menjalankan profesinya. Perawat diharapkan mampu memberikan asuhan keperawatan kepeda individu sesuai diagnosis yang ditetapkan. Dan menggunakan proses keperawatan untuk mengetahui diagnosis keperawatan mulai dari masalah fisik sampai masalah psikilogis.

Dalam memberikan asuhan dan layanan keperawata perawat harus berusaha semaksimal mungkin tanpa membedakan-bedakan. Pelayanan yang diberikan harus merata secata adil. Dalam menjalankan perannya perawat tidak boleh memanadang pasien dari sosial, budaya, suku, ras dan agama. Perawat diharapkan mampu memberikan asuhan keperawatan kepada paien dengan kepercayaan penuh berdasarkan budaya dan keyakinan pasien. Dalam hal tersebutlah perawat memiliki tuntutan agar tetap peka dan mampu mendukug dan mampu mensejahterakan pasien. Tidak boleh anggapan membeda-bedakan dan setiap layanan yang diberikan harus sesuai dengan kebutuhan dan keadilan. Tingkat kesempurnaa dalam memberikan asuhan keperawatan sangat bergantung dengan kemauan, kemampuan, pengetahuan dan keterampilan yang baik dari perawat. Selain itu juga harus didukung dengan ketersediaanfasilitas secara memadai, kondisi kuantitas yang sesuai penempatan yang tepat serta persiapan sumber daya manusia(perawat) yang baik pula. Selanjutnya hal lain yang perlu diperhatikan ketika hendak memberikan asuhan keperawatan adalah ketersediaan peralatan kesehatan yang memadai. Segala tindakan yang dilakukan perawat harus teliti dan tidak boleh 
lalai, agar tidak terjadi hal-hal yang merugikan. Dengan kerugian atas kelalaian pelayanan yang diberikan perawat dalam menjalankan tugas dan wewenang, maka pasien selaku penerima tindakan berhak mendapatkan perlindungan sesuai dengan Undang-Undang Nomor 8 Tahun 1999 tentang perlindungan konsumen. Dengan memberikan asuhan yang baik maka pasien akan lebih senang sehingga berkurangnya kekhawatiran yang dialami, dan bisa mempercepat proses penyembuhannya.

\section{PENUTUP.}

Dalam memberikan asuhan keperawatan perawat dituntut untuk memiliki kepekaan dan kemampuan untuk membantu kesejahteraan pasien, dan membina kepercayaan melalui tindakan dan cara kita dalam bertindak. Kefrofesionalan perawat dalam memberikan pelayanan akan mamiliki pengaruh yang signifikat terhadap proses perawatan pasien di rumah sakit.

\section{REFERENSI}

Aeni, W.,N.,dkk.(2019). Perilaku Caring Perawat dalam Memberikan Asuhan Keperawatan di Salah Satu RS di Kabupaten Indramayu. Jurnal Keperawatan Profesional, F.Kes, Unuja. 7(2).

Gobel, M.,G.,S.,dkk.(2016). Hubungan Peran Perawat Sebagai Care Giver Dengan Tingkat Kepuasan Pasien Instalasi Gawat Darurat di RSU Gmibm Monompia Kotamobagu Kabupaten Bolaang Mongondow. ejournal Keperawatan (e-Kp).4(2):1-7.

Jumariah,T.,\& M.,Budhi. (2017). Peran Perawat Dalam Pelaksanaan Perawatan Kesehatan Masyarakat (Perkesmas). Jurnal Ilmu Keperawatan Indonesia 7(1):182-188

.Maryam. (2019). Tanggung Jawab Hukum Perawat Terhadap Kerugian Pasien Dikaitkan Dengan Undang -Undang Nomor 8 Tahun 1999 Tentang Perlindungan Konsumen. e-Jurnal Katalogis. 4(10):191-201. 
Pagala, P.,dkk.(2017). Perilaku Kepatuhan Perawat Melaksanakan SOP Terhadap Kejadian Keselamatan Pasien di Rumah Sakit X Kendari. Jurnal Promosi Kesehatan Indonesia.12(1):138-149.

Setiani,Baiq.(2018).Pertanggungjawaban Hukum Perawat Dalam Hal Pemenuhan Kewajiban Dan Kode Etik Dalam Praktik Keperawatan. Jurnal Ilmiah Ilmu Keperawatan Indonesia. 8(4):497507.

Simamora, R. H. (2019). Development of Guidelines for Applying appropriate Patient Identification to Achieve Patient Safety Goal

INC2019 12th International Nursing Conference. 2019.10455 - 455 (1 pages) UCI(KEPA) : I410-ECN0101-2019-512-001224337

Simamora. R. H. (2008) The correlation of ward chief's giving direction and command and the performance of on-duty nurses at Jember dr. Subandi general hospital inpatient wards. jurnal Administrasi dan Kebijakan Kesehatan, (https://fkm.unair.ac.id/jurnal-administr)

Sulistyowati, D.,\& H,.Fitria. (2012). Peran Perawat Dalam Pelaksanaan Personal Hygiene Menurut Persepsi Pasien Imobilisasi Fisik. Jurnal Nursing Studies 1(1):169 - 174.

Wahyudi, Iwan. (2020). Pengalaman Perawat Menjalani Peran Dan Fungsi Perawat di Puskesmas Kabupaten Garut. jurnal sahabat keperawatan. 2(1):36-42.

Yuniarti, S,.\& Julaikah. (2014). Peran Perawat Sebagai Care Giver Nurse Role As a Care Giver. Jurnal Keperawatan.7(1):13-17. 
